\title{
Notes on identity and distribution of Argyreia boseana and $A$. hookeri (Convolvulaceae) in India
}

\author{
Lawand P.R. \& V.B. Shimpale* \\ Department of Botany, The New College, Kolhapur, Maharashtra - 416 012, India \\ *E-mail: shimpale@yahoo.com
}

\begin{abstract}
Confusion regarding the identity of Argyreia hookeri C.B.Clarke and A. boseana Santapau \& V.Patel, two closely similar species found in India are discussed. Notes on its distribution, morphological comparison and photographic images are provided for comparison and easy identification in the field.
\end{abstract}

Keywords: Endemic, Northeast India, Western Ghats.

\section{Introduction}

The genus Argyreia Lour. (Convolvulaceae), a native of continental Asia, with about 135 species (Staples \& Traiperm, 2017) is distributed throughout China, Indian subcontinent and Southeast Asia. Argyreia is represented by 40 taxa in India (Lawand et al., 2019) of which17 are endemic.

While collecting Argyreia specimens for a revision of the genus, the authors found that the specimens of $A$. hookeri C.B.Clarke collected from the Western Ghats differ from those collected from the type locality in Northeast India. This forced the authors to conduct a detailed examination of literature and type specimens which lead to the conclusion that the Western Ghat's specimens identified as $A$. hookeri in many Indian herbaria represents a closely similar but distinct species, $A$. boseana Santapau \& V.Patel. The confusion between these two species could be attributed to the scanty description in the protologue and overlapping characters usually found among the two species. This paper aims to present the important morphological differences between the two species for easy identification.

Received: 05.09.2019; Revised \& Accepted: 04.01.2020

Published Online: 30.06.2020
Argyreia boseana Santapau \& V.Patel, Trans. Bose Res. Inst. Calcutta 22: 35. 1958; A. hookeri sensu T.Cooke, Fl. Pres. Bombay 2: 255.1905; Venkanna \& Das Das in Singh et al., Fl. Maharashtra St. Dicot. 2: 441. 2001; S.R. Yadav \& Sardesai, Fl. Kolhapur district 369. 2002. Type: INDIA, Bombay state [Maharashtra], Satara district, near Mahabaleshwar, Fitzgerald Ghat (Ambenali Ghat), 15.07.1956, Z. Kapadia 2083 (holo BLAT!).

Fig. 1a1-e1

A moderate perennial climber, rarely prostrate; older stems semi-woody, warty, herbaceous towards apex, younger stem hairy, green sometimes purplish. Lamina widely ovate, 15-22 × 10-15 cm, apex acute to narrowly acute, base cordate, secondary veins $10-12$ pairs, nearly glabrous adaxially, sparsely hairy on veins abaxially; petioles 10-15 cm long, shorter than the peduncle, adaxially shallowly grooved, green to pale purple, sparsely hairy. Inflorescence a compact cyme, 10-15flowered; peduncles sparsely hairy, 15-25 cm long. Flowers sub-sessile; bracts 2, narrowly oblong, 2$2.5 \mathrm{~cm}$ long, sparsely hairy externally, glabrous within. Sepals unequal, outer three narrower and longer, 1.5-2 cm long, inner two shorter, 1-1.5 $\mathrm{cm}$ long, apex acuminate, glabrous within, sparsely hairy externally, persistent in fruit. Corolla pink, 5-7 × 5-6 cm; tube 2.5-3 cm long, dark purple inside, hairy on midpetaline bands; lobes shortly apiculate, twisted in bud. Stamens included in the corolla tube, 3-4 cm long; filaments white, dilated and glandular hairy at base. Fruit a fleshy berry, c. 1 $\mathrm{cm}$ in diam., yellow.

Flowering \& fruiting: Flowering in August to October and fruiting in October to January. 

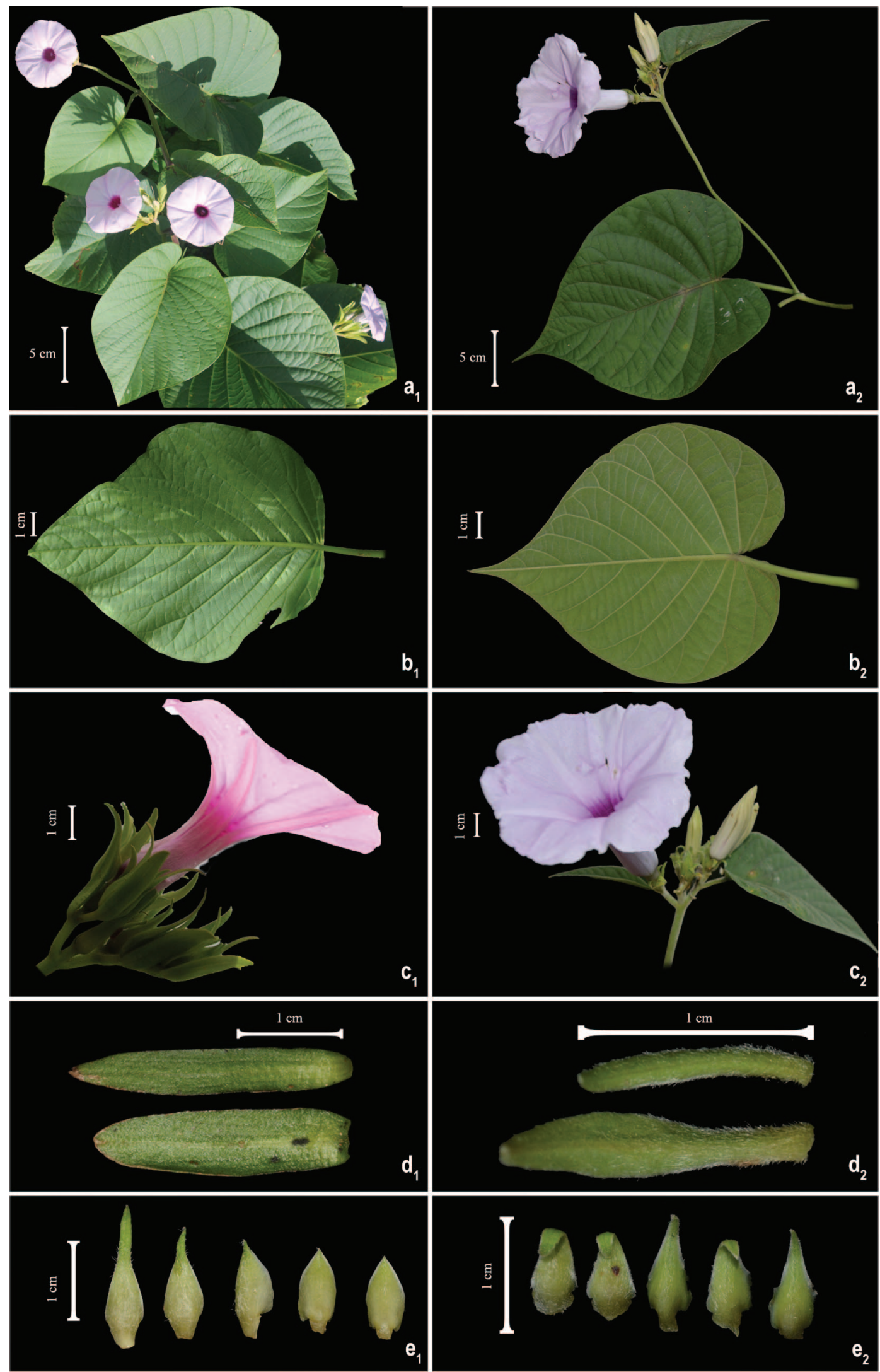

Fig. 1. Comparison of Argyreia boseana Santapau \& V.Patel (a1-e1) and Argyreia hookeri C.B.Clarke (a2-e2): a. Flowering twigs; b. Leaf-abaxial surfaces; c. Inflorescences; d. Bracts; e. Sepals. 
Distribution: Endemic to the Western Ghats of India. Specimens examined: INDIA, Karnataka, Belgaum district, Yedur, 27.08.1963, R.S. Raghavan 90270 (BSI); Shimoga district, Agumbe, 18.05.1960, R.S. Raghavan 62637 (BLAT); Uttar Kannada district, Balehalli, 30.10.1980, R. Raghavan 67943 (BLAT); Yellapur, Teligeri, 13.03.1957, S.K. Jain 16505 (BSI); Ibid., 11.03.1957, S.K. Jain 16272, 16505 (BLAT). Maharashtra, Satara district, Ambenali Ghat, 16.09.2018, P.R. Lawand 031 (New College Herbarium); Fitzgerald Ghat, Mahabaleshwar, 06.09.1954, U.M. Patel 767; Lingmala Falls, 21.12.1954, U.M. Patel 1129; Mahabaleshwar, 10.1924, R.D. Acland 759 (BLAT); Ibid., 30.01.1956, V.D. Vartak 3021, 2107; Ibid., 03.10.1955, V.D. Vartak 1186 (AHMA); Valmiki plateau, 09.09.2016, P.R. Lawand \& V.B. Shimpale 005 (SUK); Wada, Kas, 02.12.1983, S.D. Deshpande 166571 (BSI); Sindhudurg district, Phonda Ghat, 18.08.1965, B.G. Kulkarni 105572 (BSI).

Argyreia hookeri C.B.Clarke in Hook.f., Fl. Brit. India 4: 185. 1883. Rivea hookeri (C.B.Clarke) Hallier f., Bull. Herb. Boiss. 7: 60. 1899. Lectotype (designated by Shalini et al., 2017): INDIA, Sikkim, Sikkim Himalaya, 4000 m, s.d., J.D. Hooker s.n. (K [K001081783 digital image!]; isolecto K [K001081784, K000830585, K000830586, K000830588 digital images!], P [P00584821, P00584822 digital images!]).

Argyreia populifolia Choisy, Convolv. Orient. 32. 1834, p.p.; Kanjilal et al., Fl. Assam 3: 342. 1939; Balakr., Fl. Jowai 2: 328. 1983; Ghosh \& Mallick, Fl. Darjeeling Himalaya 165. 2014; Mao et al., Checkl. Fl. Meghalaya 120. 2016.

Fig. 1a2-e2

A woody climber; older stems woody, glabrous or remotely hairy, younger stems white hairy, green. Lamina widely ovate to orbicular, 10-18 × 8-14 $\mathrm{cm}$, apex abruptly acuminate, base deeply cordate, lobes round, secondary veins 9-11 pairs, depressed above, sparsely hairy adaxially, densely white sericeous abaxially, denser on veins, juvenile leaves with silky hairs; petioles $8-12 \mathrm{~cm}$ long, terete, not grooved, green, white strigose. Inflorescence loosely arranged, 6-15-flowered; peduncles 12-22 cm long, white appressed-strigose; inflorescence bracts (outer bract) leafy, stalk 3-3.5 cm long, reticulately veined, abaxially white sericeous. Flowers pedicellate; floral bracts 2, lance-ovate to oblong-linear, 1-1.5 cm long, caducous, white tomentose outside, strigulose within. Sepals subequal, c. $1 \mathrm{~cm}$ long, outer two with a reclined upper half, apex narrowly acute, glabrous within, strigose outside. Corolla rose-pink, 5-6 × 5-6 cm; tube dark purple within, hairy on midpetaline bands; corolla lobes twisted in bud. Stamens inserted, c. $0.5 \mathrm{~cm}$ above base of tube, included, raised up to half of corolla tube; filaments white, dilated and glandular hairy at base. Fruit a fleshy berry, yellow.

Flowering \& fruiting: Flowering in July to October and fruiting in October to January.

Distribution: India, Indonesia, Myanmar, Nepal and Thailand.

Specimens examined: INDIA, Meghalaya, West Jaintia Hills district, Khasi and Jaintia Hills, Mytang Valley, 20.01.1916, U. Kanjilal 6567 (ASSAM); West Garo Hills district, Nokrek National Park, near Sisubibra village, 16.10.2007, V.K. Singh \& Bikram Singh 116739 (ASSAM). Mizoram, Aizawl district, Aizawl City, 08.10.2018, P.R. Lawand 043 (SUK); Mamit district, Dampa Tiger Reserve, Lallen, 12.12.2006, N. Odyuo 113629 (ASSAM); West Phaileng, 08.10.2018, P.R. Lawand 014 (SUK). Sikkim, East Sikkim district, 1895, G.M. Gammie s.n. (BSI); Baghey Khola, 13.11.1998, S.S. Dash 20928; Saramsa, 23.08.1980, P.K. Hajra 593; Reshi Khola, 10.12.1980, P. Chakraborty 1099 (BSHC); South Sikkim district, Ratey Pani, 11.09.1981, B. Krishna 1771 (BHSC); North Sikkim district, Right Flank, Dikchu, 13.12.1997, B.K. Shukla 20315 (BHSC); West Sikkim district, Tashiding, 11.12.1994, G.P. Sinha \& S. Pradhan 15279 (BHSC). West Bengal, Darjeeling district, Darjeeling, on the way to Bagrakote, 13.10.2018, P.R. Lawand 044 (SUK); Jalpaiguri district, Poro Buxa Div., 22.11.1975, J.K. Sikdar 838 (CAL); Kalimpong district, Kalimpong, 08.08.1997, P. Sinha \& S.S. Dash 17282 (BSHC).

Notes: Argyreia hookeri is closely similar to A. boseana 
Table 1. Morphological comparison of A. boseana and A. hookeri

\begin{tabular}{|l|l|l|}
\hline Characters & A. boseana Santapu \& V.Patel & A. hookeri C.B.Clarke \\
\hline Leaf indumentum & Sparsely hairy abaxially & White tomentose abaxially \\
\hline Bracts & $\begin{array}{l}\text { Narrowly oblong, } 2-2.5 \mathrm{~cm} \text { long, } \\
\text { glabrous to sparsely hairy outside }\end{array}$ & $\begin{array}{l}\text { Lance-ovate to oblong-linear, } \\
1-1.5 \mathrm{~cm} \text { long, white tomentose outside }\end{array}$ \\
\hline Sepals & Unequal, acuminate at apex, not reflexed & Sub-equal, acute at apex, reflexed \\
\hline
\end{tabular}

in having widely ovate to orbicular leaves, longer peduncles, few to many flowered inflorescence, rose-pink corolla and yellow fleshy berries. However, A. hookeri can be distinguished by its sparsely hairy adaxial and white tomentose abaxial leaf surfaces, 6-15-flowered, dichotomously branched cymes, lance-ovate caducous bracts and outwardly reflexed lance-ovate sepals with acute apex. In addition, both the species shows a disjunct distribution. Some additional morphological differences between these taxa are given in Table 1 and Figure 1.

Based on extensive field surveys along the Western Ghats and after examining the herbarium specimens of Argyreia at AHMA, BLAT, BSI, CALI, DRC, $\mathrm{MH}$ and TBGT, it is concluded that $A$. hookeri does not occur in the Western Ghats. After careful scrutiny of our own collections and specimens at above mentioned herbaria, it is revealed that whatever specimens collected and identified as $A$. hookeri from the Western Ghats are actually belong to $A$. boseana. The original taxon identified erroneously as $A$. hookeri by Cooke (1908) was later described as A. boseana by Santapau and Patel (1958). The Cooke's concept of $A$. hookeri was, however, followed by succeeding taxonomists (Sharma et al., 1984; Venkanna \& Das Das, 2001; Ramaswamy et al., 2001; Manikandan \& Lakshminarasimhan, 2013; Nayar et al., 2014). Report on the occurrence of $A$. hookeri in Western Ghats is thus erroneous.

\section{Acknowledgements}

Authors are thankful to the authorities at AHMA, BLAT, BSI, CALI, DRC, MH, SUK and TBGT for granting permission to consult herbarium specimens, and to the Principal, The New College, Kolhapur for providing facilities. PRL is thankful
Council of Scientific and Industrial Research (CSIR), New Delhi for financial assistance.

\section{Literature Cited}

COOKE T. 1908. Flora of the Presidency of Bombay. Volume 2. Taylor \& Francis, London. pp. 254-260. https:// doi.org/10.5962/bhl.title.10884

LAWAND P.R., GAIKWAD S.V., GURAV R.V. \& V.B. SHIMPALE 2019. Karyomorphological studies in three species of Argyreia Lour. (Convolvulaceae) from India. The Nucleus 62(1):71-75. https://doi.org/ 10.1007/s13237-018-0252-9

MANIKANDAN R. \& P. LAKSHMINARASIMHAN 2013. Flora of Rajiv Gandhi National Park, Karnataka. Botanical Survey of India, Kolkata. p. 268.

NAYAR T.S., BEEGAM A.R. \& M. SIBI 2014. Flowering plants of the Western Ghats, India. Volume 1. Jawaharlal Nehru Tropical Botanical Garden \& Research Institute, Thiruvananthapuram. p. 143.

RAMASWAMY S.N., RAO M.R. \& G.D. AREKAL 2001. Flora of Shimoga district, Karnataka. University Printing Press, Mysore. p. 397.

SANTAPAU H. \& V. PATEL 1958. The Convolvulaceae of Bombay: Additions and Corrections. Transactions of Bose Research Institute 22: 33-42.

SHARMA B.D., SINGH N.P., RAGHAVAN R.S. \& U.R. DESHPANDE 1984. Flora of Karnataka Analysis. Botanical Survey of India, Kolkata. pp. 179-180.

SHALINI S., LAKSHMINARSIMHAN P. \& W. ARISDASON 2017. Lectotypification of four names in Argyreia (Convolvulaceae). Telopea 20: 171-177. http://dx.doi.org/10.7751/telopea11718

STAPLES G.W. \& P. TRAIPERM 2017. A nomenclatural review of Argyreia (Convolvulaceae). Taxon 66 (2): 445477. https://doi.org/10.12705/662.12

VENKANNA P. \& S.K. DAS DAS 2001. Convolvulaceae In: SINGH N.P., LAKSHMINARSIMHAN P., KARTHIKEYAN S. \& P.V. PRASANNA (eds.), Flora of Maharashtra State. Volume 2. Botanical Survey of India, Kolkata. pp. 439-448. 